\title{
ANALISIS HUKUM MENGENAI PERLINDUNGAN KONSUMEN DALAM PERJANJIAN PENGIKATAN JUAL BELI TANAH BERIKUT BANGUNAN (KASUS DI PT. X)
}

\author{
R. Affitantho S. $^{1}$
}

\begin{abstract}
Abstrak
The author does analysis from his research concerning real estate 'housing' transaction case. The main focus of research is embarked on the developer failed to delivery land and built housing to their customer during agreement periods. Normatively the author thought that the developer has committed a breach the contract and broken the law by their fall short to delivery fulfil. At the case detail the developer duty to delivery land and built housing is agreed in the contract of sale and its annex. Analysis offered here also fall into common contractual law issues such as standard contract violence, and good faith principle which have regulated in laws and regulations. The scope of the effective laws and regulations are from Indonesian Civil Code to the specific land, housing law norms are exercised in this research analysis.
\end{abstract}

Kata kunci: Hukum Keperdataan, perjanjian, jual beli, tanah, bangunan rumah, perlindungan konsumen

\section{Pendahuluan}

Salah satu kebutuhan dasar bagi manusia adalah berupa rumah atau tempat tinggal, yang merupakan tempat tinggal baik tetap maupun sementara, sekaligus merupakan tempat perlindungan bagi dirinya maupun keluarganya. Penyediaan tempat tinggal atau rumah semakin lama semakin sulit untuk didapatkan bagi yang membutuhkan mengingat ketersediaan lahan untuk mendirikan bangunan tempat tinggal semakin lama jumlahnya semakin terbatas khususnya untuk lahan yang berada didaerah perkotaan.

Dalam rangka memenuhi kebutuhan pokok tersebut maka Pemerintah memberikan kesempatan bagi pihak swasta untuk turut serta menyediakan rumah-rumah berikut sarananya (komplek perumahan) bagi yang membutuhkan, sebagaimana yang tercantum dalam pasal 23 UU No. 4 tahun

\footnotetext{
${ }^{1}$ Penulis adalah Managing Partners pada Kantor Advokat dan Konsultan Hukum DAFI \& REKAN, Jakarta.
} 
1992 tentang Perumahan dan Pemukiman, dimana badan usaha dibidang pembangunan perumahan (pihak swasta) dapat menyediakan perumahan di kawasan siap bangun atau di lingkungan siap bangun yang berdiri sendiri.

Meskipun banyak pihak swasta yang bergerak di bidang perumahan selaku pengembang (developer) akan tetapi masih relatif sulit untuk memperoleh tempat tinggal yang layak huni pada perumahan serta tidak merugikan masyarakat.

Selain tingginya nilai jual juga banyak kendala lainnya bagi masyarakat yang membutuhkan tempat tinggal pada perumahan seperti adanya satu atau lebih fasilitas yang tidak dapat dipenuhi oleh pihak pengembang, adanya ijin-ijin yang bermasalah, masih adanya sertipikat tanah yang bermasalah atau dengan kata lain masih adanya sebagian janji-janji pihak pengembang yang tidak dapat dipenuhi dan merugikan masyarakat.

Sejak berlakunya Undang-undang Nomor 5 Tahun 1960 tentang Peraturan Dasar Pokok-pokok Agraria (UUPA) dan Undang-undang Nomor 16 Tahun 1985 tentang Ketentuan-ketentuan Mengenai Rumah Susun (UURS), pengalihan hak atas tanah maupun hak atas satuan rumah susun di Indonesia sepenuhnya harus mengikuti ketentuan sebagaimana diatur dalam Undang-undang tersebut dan peraturan pelaksanaannya, termasuk Peraturan Pemerintah Nomor 24 Tahun 1997 tentang Pendaftaran Tanah, yang berisikan ketentuan-ketentuan penting mengenai kegiatan yang wajib dilakukan setelah adanya peralihan hak atas tanah di Indonesia yaitu wajib dilakukannya pendaftaran di kantor Pertanahan setempat dengan akta yang dibuat oleh Pejabat Pembuat Akta Tanah (PPAT) sebagaimana yang diamanatkan oleh UUPA dalam pasal 19 ayat (1) jo pasal 23, 32 dan pasal 38 .

Akan tetapi masih adanya jual beli tanah berikut bangunan pada pengembang yang tidak langsung dilakukannya pengalihan hak atas tanah berikut bangunan secara hukum sebagaimana yang diatur dalam ketentuan perundang-undangan sebagaimana tersebut di atas, melainkan para pihak membuat suatu perjanjian mengenai jual beli atas tanah berikut bangunan atau lebih dikenal dengan istilah Perjanjian Pengikatan Jual Beli Tanah dan Bangunan (selanjutnya disebut PPJB).

Permasalahan tersebut di atas dapat merugikan konsumen (pembeli) apabila konsumen tersebut telah melunasi harga jual tersebut dan pihak pengembang tidak dapat memenuhi janjinya untuk membuat Akta Jual Beli (lebih dikenal dengan istilah AJB) dihadapan PPAT, sebagaimana yang diatur dalam Pasal 37 Peraturan Pemerintah Nomor 24 Tahun 1997 tentang Pendaftaran Tanah, maupun yang diperjanjikan dalam PPJB.

Hal tersebut di atas dikarenakan adanya kesenjangan antara pihak pengembang selaku produsen dan masyarakat selaku konsumen perumahan, 
sehingga konsumen berada pada posisi tawar yang lebih lemah dimana konsumen perumahan dapat menjadi obyek dari aktifitas bisnis pihak produsen.

\section{Pokok Permasalahan}

Pokok permasalahan yang akan diangkat penulis dalam penulisan skripsi ini adalah:

1. Bagaimana ketentuan hukum mengenai peralihan hak atas tanah berikut bangunan pada kasus yang akan diteliti?

2. Bagaimana ketentuan hukum yang mengatur mengenai hak dan kewajiban para pihak yang timbul dari adanya Perjanjian Pengikatan Jual Beli atas tanah berikut bangunan?

3. Bagaimana pengaturan perlindungan konsumen di dalam Perjanjian Pengikatan Jual Beli atas tanah berikut bangunan?

\section{Kerangka Teori}

Jual beli merupakan salah satu cara yang paling umum dilakukan dalam memperoleh atau mengalihkan hak atas tanah ataupun rumah, baik yang dimiliki oleh subyek hukum orang maupun yang berupa badan hukum.

Akan tetapi tidak jarang terjadi pada masyarakat sebelum dilakukan jual beli tersebut, terlebih dahulu dilakukan suatu Perjanjian yang mengikat antara para pihak yang membuatnya atau sering disebut Perjanjian Pengikatan Jual Beli (PPJB). Hal tersebut dilakukan oleh karena adanya satu dan lain hal yang menyebabkan jual beli atas tanah tidak dapat dilakukan pada saat itu juga.

Dengan telah diberlakukannya Undang-undang berikut peraturanperaturan pelaksanaannya tersebut di atas, maka walaupun tanah berikut bangunan di atasnya merupakan salah satu kebutuhan pokok manusia, untuk dapat memperoleh atau menguasainya baik dengan cara perolehan atas hak baru maupun peralihan hak tidak dibenarkannya adanya unsur paksaan dalam bentuk apapun dan oleh pihak siapapun, serta diperlukan alas hak yang disediakan oleh hukum tanah nasional (hukum positif). 


\section{Perjanjian Pengikatan Jual Beli}

Suatu perjanjian dapat dikatakan sah menurut hukum apabila memenuhi syarat sah perjanjian, yaitu sepakat, kecakapan, hal tertentu dan sebab yang halal, sebagaimana diatur dalam pasal 1320 KUHPerdata.

Dua syarat pertama merupakan syarat subyektif, yaitu dengan melihat subyek dari para pihak pembuat perjanjian, sedangkan dua syarat berikutnya merupakan syarat obyektif yaitu dengan melihat obyek yang diperjanjikan oleh para pihak. Dalam hal tidak dipenuhinya syarat subyektif maka perjanjian tersebut batal demi hukum (null and void), sedangkan dengan tidak terpenuhinya syarat obyektif, maka perjanjian tersebut dapat dimintakan pembatalannya pada Hakim (voidable) atau perjanjian tersebut selalu diancam bahaya pembatalan. ${ }^{2}$

Perjanjian yang merupakan hukum pelengkap (optional law), maka dalam suatu Perjanjian Pengikatan Jual Beli dapat mengesampingkan pasalpasal yang diatur dalam Buku III KUHPerdata, sebagaimana yang terdapat dalam pasal 1338 ayat (1) KUHPerdata, yang menyebutkan bahwa "semua perjanjian yang dibuat secara sah berlaku sebagai undang-undang bagi para pihak yang membuatnya". Sehingga jelas bahwa dapat dibuat perjanjian yang berisikan apa saja asalkan tidak melanggar undang-undang, ketertiban umum dan kesusilaan atau lebih dikenal sebagai asas kebebasan berkontrak.

Dilihat dari syarat sahnya perjanjian dan asas kebebasan berkontrak, Asser membedakan bagian isi perjanjian, bagian inti (wezenlijk oordeel) yaitu unsur essensilia dan bagian yang bukan inti (non wezenlijk oordeel) yaitu unsur naturalia dan unsur aksidentalia. ${ }^{3}$

Unsur essensialia merupakan sesuatu yang harus ada dan merupakan hal pokok sebagai syarat yang tidak boleh diabaikan dan harus dicantumkan dalam suatu perjanjian, sehingga perjanjian tanpa hal pokok tersebut tidak sah atau cacat dan tidak mengikat para pihak, sebagai contoh unsur essensilia dalam jual beli adalah harga dan barang.

Unsur naturalia merupakan unsur-unsur yang biasanya dijumpai dalam perjanjian tertentu, namun tanpa pencantuman syarat yang dimaksud itupun, suatu perjanjian tetap sah dan mengikat para pihak yang membuatnya, kecuali dinyatakan sebaliknya, sebagai contoh dalam jual beli tidak diperjanjikan mengenai siapa yang berkewajiban membayar biaya balik

${ }^{2}$ Subekti (A), Op.Cit., hal. 20.

${ }^{3}$ Mariam Darus Badarulzaman, "KUHPerdata Buku III Hukum Perikatan Dengan Penjelasannya", cet.2, (Bandung: Alumni, 1993), hal. 99. 
nama, maka ketentuan undang-undang yang berlaku yaitu pasal 1466 KUHPerdata.

Unsur aksidentalia merupakan suatu syarat yang tidak harus ada, tetapi dicantumkan juga oleh para pihak untuk keperluan tertentu dengan maksud khusus sebagai penegasan dan sebagai suatu kepastian. ${ }^{4}$

Selain hal tersebut di atas, suatu perjanjian hendaklah memenuhi rasa keadilan yang berkeseimbangan bagi para pihak, dimana perjanjian tersebut memenuhi asas persamaan hukum dan asas keseimbangan.

Dalam rumusan pasal 1457 yang dimaksud dengan jual beli adalah suatu perjanjian dengan mana pihak yang satu mengikatkan dirinya untuk menyerahkan suatu kebendaan dan pihak yang lain untuk membayar harga yang telah dijanjikan.

Berdasarkan rumusan yang diberikan tersebut dapat dilihat bahwa jual beli merupakan suatu bentuk perjanjian yang melahirkan kewajiban atau perikatan untuk memberikan sesuatu (perjanjian timbal balik), yang dalam hal ini terwujud dalam bentuk penyerahan uang oleh pembeli kepada penjual. Teori dari perjanjian timbal balik seringkali juga disebut perjanjian bilateral. Perjanjian timbal balik adalah perjanjian yang menimbulkan kewajibankewajiban (dan karenanya hak juga) kepada kedua belah pihak, dan hak serta kewajiban itu mempunyai hubungan yang satu dengan yang lainnya. Yang dimaksud dengan "mempunyai hubungan antara yang satu dengan yang lainnya" adalah bahwa bilamana dalam perikatan yang muncul dari perjanjian tersebut, yang satu mempunyai hak, maka pihak yang lain sebagai pihak yang memikul tanggung jawab. Pembagian di sini didasarkan atas perikatan yang muncul dari perjanjian tersebut, apakah mengikat satu pihak saja ataukah mengikat kedua belah pihak. ${ }^{5}$ Jadi dalam perjanjian jual beli, yang dijanjikan oleh pihak yang satu (pihak penjual), menyerahkan atau memindahkan hak miliknya atas suatu barang yang ditawarkan, sedangkan yang dijanjikan oleh pihak yang lain, membayar harga yang telah disetujuinya. ${ }^{6}$

Jual beli adalah suatu perjanjian konsensuil, artinya, perjanjian tersebut sudah dilahirkan sebagai suatu perjanjian yang sah (mengikat atau mempunyai kekuatan hukum) pada detik tercapainya sepakat antara penjual dan pembeli mengenai unsur-unsur yang pokok (essentialia) yang barang dan

${ }^{4}$ I.G. Rai Widjaya, "Merancang Suatu Kontrak Teori Dan Praktek", cet.2, (Jakarta: Megapoin, 2002), hal. 93-94.

\footnotetext{
${ }^{5}$ J. Satrio, Op. Cit., hal. 43-44.

${ }^{6}$ Subekti (A), Op. Cit., hal. 79.
} 
harga, biarpun jual beli itu mengenai barang yang tak bergerak. Sifat konsensuil jual beli ini ditegaskan dalam Pasal 1458 yang berbunyi:

Jual beli dianggap telah terjadi antara kedua belah pihak sewaktu mereka telah mencapai sepakat tentang barang dan harga, meskipun barang itu belum diserahkan maupun harganya belum dibayar.

Jadi jual beli melibatkan eksistensi dan sekurangnya dua perikatan (untuk memberikan sesuatu) secara bertimbal balik. Ini berarti dalam jual beli secara tidak langsung juga, jika memenuhi syarat sahnya perjanjian sebagimana disebutkan dalam Pasal 1320 KUHPerdata menerbitkan atau melahirkan prestasi dan pertangungjawaban secara bertimbal balik pada kedua belah pihak yang ada dalam jual beli tersebut, yaitu penjual dan pembeli.

Barang yang menjadi obyek perjanjian jual beli harus cukup tertentu, setidak-tidaknya dapat ditentukan wujud dan jumlahnya pada saat ia akan diserahkan miliknya kepada si pembeli. ${ }^{7}$

Salah satu sifat yang penting dari jual beli menurut sistem KUHPerdata, adalah bahwa perjanjian jual beli itu hanya obligatior saja, artinya menurut sistem KUHPerdata, jual beli itu belum memindahkan hak milik, ia baru memberikan hak dan meletakkan kewajiban pada kedua belah pihak, yaitu memberikan kepada si pembeli untuk menuntut diserahkannya hak milik atas barang yang dijual. ${ }^{8}$ Apa yang dikemukakan mengenai sifat jual beli tersebut, nampak jelas diterangkan dalam Pasal 1459 KUHPerdata, yang berbunyi:

Hak milik atas barang yang dijual tidaklah berpindah tangan kepada si pembeli selama penyerahannya belum dilakukan menurut Pasal 612, 613, dan 616.

Berhubungan dengan sifat jual beli tersebut, maka tidak mudah untuk dapat dimengerti yang dimaksud dalam Pasal 1471 yang mengatakan:

${ }^{7}$ R. Subekti (C), "Aneka Perjanjian", cet. Kesepuluh, (Bandung: Penerbit PT. Citra Aditya Bakti, 1995), hal. 2.

${ }^{8}$ Subekti (A), Op. Cit., hal. 80. 
Jual beli barang orang lain adalah batal, dan dapat memberikan dasar untuk ganti rugi, jika si pembeli tidak mengetahui bahwa barang itu kepunyaan orang lain.

Kalau memang jual beli itu hanya bersifat obligatior saja, yang berarti belum memindahkan hak milik, tentulah tidak keberatan apabila seorang menjual sesuatu barang yang belum menjadi kepunyaannya, asal nanti pada waktu ia harus menyerahkan barang tersebut, ia benar-benar menjadi pemilik barang tersebut. Pasal 1460 sebagaimana dengan Pasal 1471, tanpa disadari bahwa pasal tersebut dalam sistem KUHPerdata yang menentukan saat pemindahan hak milik pada detik dilakukannya penyerahan, tidaklah tepat. ${ }^{9}$

Dalam Pasal 1460 terdapat keganjilan, dan tepat sekali oleh para sarjana dan yurisprudensi dibatasi keberlakuannya, hingga hanya mengenai barang tertentu saja. Artinya barang tertentu adalah, suatu barang yang sudah ditunjuk dan ditentukan oleh kedua belah pihak. ${ }^{10}$

Si penjual mempunyai dua kewajiban utama, yaitu menyerahkan barangnya dan menanggungnya. Menyerahkan adalah memindahkan barang yang telah dijual itu menjadi milik si pembeli. Jadi penyerahan itu suatu perbuatan hukum yang harus dilakukan untuk memindahkan hak milik dari satu ke orang lain, dari si penjual kepada si pembeli. Biaya penyerahan harus dipikul oleh si penjual, sedangkan biaya pengambilan harus dipikul oleh si pembeli, jika tidak diperjanjikan sebaliknya (Pasal 1476 KUHPerdata).

Ini berarti dalam suatu perjanjian, baik yang melahirkan perikatan untuk memberikan sesuatu, perikatan untuk berbuat sesuatu atau perikatan untuk tidak berbuat sesuatu, senantiasa haruslah ditentukan terlebih dahulu kebendaan yang akan menjadi obyek dalam perjanjian, yang selanjutnya akan menjadi obyek dalam perikatan yang lahir (baik secara bertimbal balik atau tidak) diantara para pihak yang membuat perjanjian tersebut. Dengan demikian jelaslah bahwa tanpa adanya kebendaan tertentu yang menjadi obyek perjanjian, prestasi, atau kewajiban atau utang tidak pernah ada.

\section{A. Keabsahan Perjanjian Pengikatan Jual Beli}

Dalam rumusan Pasal 1446 KUHPerdata, dapat diketahui bahwa selama dan sepanjang ketidakcakapan tidak dikuatkan, maka perjanjian yang dibuat oleh mereka yang cakap tersebut tidak memiliki tanggungjawab sama sekali, dan karenanya pula tidak memberikan hak

\footnotetext{
${ }^{9}$ Ibid., hal. 82 .

${ }^{10}$ Ibid., hal. 83 .
} 
menuntut harta kekayaan pada salah satu pihak terhadap siapa mereka telah membuat perjanjian. Bunyi Pasal 1446 KUHperdata tersebut adalah:

Semua perikatan yang dibuat oleh orang-orang anak yang belum dewasa, atau orang-orang yang berada di bawah pengampuan adalah batal demi hukum dan atas tuntutan yàng dimajukan oleh atau dari pihak mereka, harusnya dinyatakan batal semata-mata atas dasar kebelum dewasaan dan pengampuannya.

Perikatan-perikatan yang dibuat oleh orang-orang perempuan dan orang-orang belum dewasa yang telah mendapat suatu pernyataan persamaan dengan orang dewasa, hanyalah batal demi hukum, sekedar perikatanperikatan tersebut melampaui kekuasaan mereka.

Dengan demikian berarti, setiap pihak yang cakap bertindak dalam hukum, yang membuat perjanjian jual beli dengan orang yang tidak cakap yang telah melaksanakan kewajibannya menurut jual beli yang telah disepakati, atas tuntutannya terhadap salah satu pihak yang tidak cakap tersebut, senantiasa diancam dengan pembatalan perjanjian menurut ketentuan Pasal 1454 ayat (2) KUHPerdata dengan konsekuensi bahwa menurut ketentuan Pasal 1451 KUHPerdata bahwa pembatalan sebagai akibat ketidakcakapan membawa akibat bahwa segala apa yang telah diberikan atau dibayarkan kepada orang-orang yang tidak berkuasa, sebagai akibat pelaksanaan jual beli tersebut, hanya dapat dituntut kembali sekedar barang yang bersangkutan masih berada di tangan orang tak berkuasa tersebut, atau sekedar ternyata bahwa orang ini telah mendapat manfaat dari apa yang telah diberikan atau dibayarkan itu atau bahwa apa yang dinikmati telah dipakai atau berguna bagi kepentingannya. ${ }^{11}$ Dalam konteks demikian, tidaklah berarti kebendaan yang diserahkan kepada seorang yang tidak cakap untuk bertindak dalam hukum tidak memperoleh penggantian.

Sifat konsensual dari jual beli adalah terjadinya kesepakatan dari para pihak. Dengan kesepakatan dimaksudkan bahwa kedua belah pihak yang bersangkutan tercapai suatu kesesuaian kehendak, artinya, apa yang dikehendaki oleh yang satu adalah juga dikehendaki pihak lain. Dalam perjanjian jual beli, asas konsensualisme tersebut dapat

"Gunawan Widjaja dan Kartini Mulyadi, "Jual Beli", (Jakarta: PT. Raja Grafindo Persada, 2003), hal. 36. 
disimpulkan dari Pasal 1320 KUHPerdata, yaitu pasal yang mengatur tentang syarat-syarat sahya suatu perjanjian dan tidak dari Pasal 1338 ayat (1), yanga dalam pasal tersebut dinyatakan tentang kekuatan perjanjian, yaitu kekuatan yang sama dengan suatu undang-undang. Kekuatan seperti itu diberikan kepada "semua perjanjian dibuat secara sah", yang artinya dalam Pasal 1320 telah disebutkan satu persatu syarat-syarat untuk perjanjian yang sah itu. ${ }^{12}$

Hukum Perjanjian pada asasnya merupakan hukum pelengkap, kedua belah pihak diperbolehkan dengan janji khusus, memperluas atau mengurangi kewajiban-kewajiban yang ditetapkan oleh undangundang, bahkan kedua belah pihak diperbolehkan mengadakan perjanjian bahwa si penjual tidak akan diwajibkan menanggung suatu apapun. Namun ini ada batasannya, yaitu sebagai berikut: ${ }^{13}$

1. Meskipun telah diperjanjikan bahwa si penjual tidak akan menanggung sesuatu apapun, namun ia tetap bertanggungjawab tentang suatu akibat dari suatu perbuatan yang telah dilakukan olehnya. Segala persetujuan yang bertentangan dangan hal ini adalah batal seperti yang disebutkan dalam Pasal 1494 KUHPerdata.

2. Si penjual, dalam hal adanya janji sama, jika terjadi suatu penghukuman terhadap si pembeli untuk menyerahkan barangnya kepada seorang lain, diwajibkan mengembalikan harga pembelian, kecuali apabila si pembeli pada waktu dilakukan, mengetahui adanya putusan Hakim untuk menyerahkan barang yang dibelinya itu atau jika ia telah membeli barang tadi dengan pernyataan akan memikul sendiri untung ruginya, (Pasal 1495 KUHPerdata).

Dengan demikian maka yang menjadi alat pengukur tentang tercapainya persesuaian kehendak tersebut adalah pernyataanpernyataan yang telah dilakukan oleh kedua belah pihak dalam perjanjian jual beli. Pernyataan timbal balik dalam perjanjian jual beli oleh kedua belah pihak merupakan sumber untuk menetapkan hak dan kewajiban diantara mereka. Undang-undang berpangkal pada asas konsensualisme, namun untuk menilai apakah telah tercapai konsensus harus mengacu pada pernyataan-pernyataan yang telah dilakukan oleh kedua belah pihak, dan ini merupakan suatu tuntutan kepastian hukum. Kemudian, jika terjadi perselisihan tentang apakah terdapat konsensus

\footnotetext{
${ }^{12}$ Subekti (C), Op. Cit., hal. 4.

${ }^{13}$ Subekti (A), Op. Cit., hal. 84.
} 
atau tidak, apakah telah dilahirkan suatu perjanjian atau tidak, maka Hakim atau Pengadilanlah yang akan menetapkannya. ${ }^{14}$

Dalam perjanjian jual beli atau yang disebut juga perjanjian timbal balik, hanya berlaku Pasal 1266 KUHPerdata, yang berbunyi:

Syarat batal selalu dipersangkakan ada dalam perjanjian timbal balik,dalam hal salah satu pihak tidak memenuhi kewajibannya.

Dengan demikian, maka kalau perjanjian yang ditutup adalah perjanjian timbal balik, dan salah satu pihaknya tidak memenuhi kewajiban perikatan sebagaimana mestinya, maka pihak yang lawan janjinya berhak menuntut pembatalan perjanjian yang mereka tutup, seakan-akan para pihak memang menutup perjanjian tersebut dengan syarat seperti itu. Masalah ini juga sehubungan dengan adanya tangkisan, bahwa pihak lawan janjipun tidak memenuhi kewajiban perikatan (exceptio adempleti contractus). ${ }^{15}$

\section{B. Kewajiban Para Pihak Perjanjian Pengikatan Jual Beli}

\section{Kewajiban Pihak Penjual}

Dari ketentuan umum mengenai perikatan untuk menyerahkan sesuatu (Pasal 1235 KUHPerdata), dan ketentuan yang diatur secara khusus dalam ketentuan jual beli dalam Pasal 1471 KUHPerdata, penjual memiliki 2 (dua) kewajiban pokok, mulai dari sejak jual beli terjadi menurut ketentuan Pasal 1458 KUHPerdata, kewajiban tersebut adalah:

1. Kewajiban menyerahkan hak milik

Kewajiban menyerahkan hak milik meliputi segala perbuatan yang menurut hukum diperlukan untuk mengalihkan hak milik atas barang yang diperjual belikan itu dari si penjual kepada si pembeli. Oleh karena KUHPerdata mengenal tiga macam barang yaitu, barang bergerak, barang tetap, dan barang tak bertubuh, maka menurut KUHPerdata juga ada 3 (tiga) macam penyerahan hak milik yang masing-masing berlaku untuk masing-masing barang itu, yaitu:

${ }^{14}$ Subekti (C), Op. Cit., hal. 6.

${ }^{15}$ J. Satrio, Op. Cit., hal. 46-47. 
a. Untuk barang bergerak cukup dengan penyerahan kekuasaan barang tersebut, seperti yang disebutkan dalam Pasal 612 KUHPerdata yang berbunyi:

Penyerahan kebendaan bergerak, terkecuali yang tak bertubuh dilakukan dengan penyerahan yang nyata akan kebendaan itu oleh atau atas nama pemilik, atau dengan penyerahan kunci-kunci dari bangunan dalam mana kebendaan itu berada.

Penyerahan tidak perlu dilakukan apabila kebendaan yang harus diserahkan, dengan alasan hak lain, telah dikuasai oleh orang yang hendak menerimanya.

Dari ketentuan tersebut dapat kita lihat adanya kemungkinan menyerahkan kunci saja kalau yang dijual adalah barangbarang yang berada dalam suatu gudang, hal mana merupakan suatu penyerahan kekuasaan secara simbolis, sedangkan apabila barangnya sudah berada dalam kekuasaan si pembeli, penyerahan cukup dilakukan dengan suatu pernyataan saja. Cara yang terakhir ini dikenal dengan naman 'traditio brevi manu', yang berarti 'penyerahan dengan tangan pendek'.

b. Untuk barang tetap (tak bergerak) dengan perbuatan yang dinamakan balik nama dimuka Pegawai Kadaster yang juga dinamakan Pegawai Balik Nama atau Pegawai Penyimpan Hipotik, yaitu menurut Pasal 616 KUHPerdata dihubungkan dengan Pasal 620 KUHPerdata. Dalam pada itu segala sesuatu yang mengani TANAH, dengan mencabut semua ketentuan yang termuat dalam Buku II KUHPerdata tersebut, sudah diatur dalam Undang-Undang No. 5 Tahun 1960 tentang Pokok Agraria. Selanjutnya Peraturan Pemerintah No. 10 tahun 1961, yang merupakan peraturan pelaksana dari undang-undang tersebut, dalam Pasal 19 menentukan bahwa jual beli tanah harus dibuktikan dengan suatu akte yang dibuat oleh dan dihadapan Pejabat Pembuat Akte Tanah, sedangkan menurut maksud peraturan tersebut hak milik atas tanah juga berpindah pada saat dibuatnya akta di hadapan pejabat tersebut.

c. Untuk barang tak bertubuh dengan perbuatan yang dinamakan "cessie", sebagaimana diatur dalam Pasal 613 KUHPerdata. Sebagimana diketahui KUHPerdata 
menganut sistem bahwa perjanjian jual beli itu hanya obligatoir saja, artinya bahwa perjanjian jual beli baru meletakkan hak dan kewajiban bertimbal balik antara kedua belah pihak, yaitu meletakkan kepada si penjual untuk meyerahkan hak milik atas barang yang dijualnya, sekaligus memberikan hak kepadanya untuk menuntut pembayaran harga yang telah disepakati dan di sisi lain meletakkan kewajiban kepada si pembeli untuk membayar harga barang sebagai imbalan haknya untuk menuntut penyerahan hak milik atas barang yang dibelinya. Dengan perkataan lain, perjanjian jual beli menurut KUHPerdata itu belum memindahkan hak milik. Adapun hak milik baru berpindah dengan dilakukan penyerahan, yang caranya ada tiga macam tergantung dari macamnya barang.

2. Kewajiban menanggung tenteram atas barang tersebut dan menanggung terhadap cacad-cacad yang tersembunyi.

3. Kewajiban untuk menanggung kenikmatan tenteram merupakan konsekwensi daripada jaminan yang oleh penjual diberikan kepada pembeli bahwa barang yang akan dijual dan dilever itu adalah sungguh-sungguh miliknya sendiri yang bebas dari suatu beban atau tuntutan dari suatu pihak. Kewajiban tersebut menemukan realisasinya dalam kewajiban untuk memberikan penggantian kerugian jika sampai terjadi si pembeli karena suatu gugatan dari pihak ketiga, dengan putusan hakim dihukum untuk menyerahkan barang yang telah dibelinya kepada pihak ketiga tersebut. Atau juga si pembeli, sewaktu digugat di muka Pegadilan oleh pihak ketiga dapatlah ia meminta kepada hakim agar supaya si penjual diikutsertakan didalam proses yang akan datang atau sedang berjalan. Hukum perjanjian adalah hukum pelengkap, kedua belah pihak diperbolehkan dengan janji-janji khusus memperluas atau mengurangi kewajibankewajiban yang ditetapkan oleh undang-undang, bahkan mereka diperbolehkan mengadakan perjanjian bahwa si penjual tidak akan diwajibkan menanggung suatu apapun, tetapi ada batasan-batasannya seperti yang telah disebutkan sebelumnya dalam skripsi ini. Jika dijanjikan penanggungan, atau jika tentang itu tidak ada suatu perjanjian, si pembeli berhak, dalam halnya suatu penghukuman untuk 
menyerahkan barang yang akan dibelinya kepada orang lain, menuntut kembali kepada si penjual:

1. pengembalian uang harga pembelian;

2. pengembalian hasil-hasil jika ia diwajibkan menyerahkan hasil-hasil itu kepada si pemilik sejati yang melakukan tuntutan penyerahan;

3. biaya yang dikeluarkan berhubung dengan gugatan si pembeli untuk ditanggung, begitu pula biaya yang telah dikeluarkan oleh si penggugat asal;

4. penggantian kerugian beserta biaya perkara mengenai pembelian dan penyerahannya, sekedar itu telah dibayar oleh si pembeli.

Jika pada waktu dijatuhkannya hukuman untuk menyerahkan barangnya kepada seorang lain, barang itu telah merosot harganya, maka si penjual tetap diwajibkan mengembalikan harga seutuhnya. Sebaliknya jika barangnya pada waktu dijatuhkan putusan untuk menyerahkan kepada orang lain, telah bertambah harganya meskipun tanpa suatu perbuatan dari si pembeli, si penjual diwajibkan membayar kepada si pembeli apa yang melebihi harga pembelian itu juga. Selanjutnya si penjual diwajibkan mengembalikan kepada si pembeli segala biaya yang telah dikeluarkan untuk pembetulan dan perbaikan yang perlu pada barangnya.

\section{Kewajiban Pihak Pembeli}

Kewajiban utama si pembeli adalah membayar harga pembelian pada waktu dan di tempat sebagaimana ditetapkan menurut perjanjian. Harga tersebut berupa sejumlah uang. Meskipun mengenai hal ini tidak ditetapkan dalam suatu pasal undang-undang, namun sudah dengan sendirinya terdapat dalam pengertian jual beli, karena jika tidak, maka itu akan merubah perjanjiannya menjadi 'tukar menukar', atau kalau harga itu sudah berupa jasa, perjanjiannya kan menjadi suatu perjanjian kerja. Dalam pengertian jual beli sudah terdapat pengertian bahwa disatu pihak ada barang dan dilain pihak ada uang. Harga itu harus ditetapkan oleh kedua pihak, namun adalah diperkenankan untuk memperkirakan atau penentuan orang pihak ketiga. Dalam hal yang demikian, maka jika pihak ketiga ini tidak suka atau tidak mampu membuat perkiraan tersebut atau menentukannya, maka tidaklah terjadi suatu pembelian (Pasal 1465 KUHPerdata). Hal 
ini berarti bahwa perjanjian jual beli yang harganya harus ditetapkan oleh pihak ketiga itu pada hakekatnya adalah suatu perjanjian dengan suatu "syarat tangguh", karena perjanjiannya baru akan jadi kalau hàrga itu sudah ditetapkan oleh orang ketiga tersebut. Jika pada waktu membuat perjanjian tidak ditetapkan tentang tempat dan waktu pembayaran, maka si pembeli harus membayar di tempat dan pada waktu dimana penyerahan barangnya harus dilakukan (Pasal 1514 KUHPerdata).

\section{Pelaksanaan Perjanjian Pengikatan Jual Beli Hak Atas Tanah dan Bangunan}

Jual beli merupakan salah satu cara yang sering dilakukan oleh pihak yang menginginkan suatu tanah, seperti halnya pembelian tanahtanah kavling atau berikut bangunan di atasnya pada suatu perumahan real estate.

Dalam pelaksanaan jual beli atas tanah, tidak jarang terlebih dahulu dilakukannya Perjanjian Pengikatan Jual Beli antara para pihak sebelum dilakukan jual beli di hadapan PPAT.

Perjanjian Pengikatan Jual Beli tersebut dilakukan oleh karena adanya satu dan lain hal yang menyebabkan jual beli atas tanah di hadapan PPAT tidak dapat dilakukan pada saat itu juga. Dimana para pihak satu sama lain saling berjanji untuk melaksanakan jual beli atas tanah di hadapan PPAT pada saatnya nanti.

Perjanjian Pengikatan Jual Beli atas tanah merupakan suatu perjanjian yang dibuat antara satu pihak selaku penjual/pemilik atas tanah dengan pihak lainnya selaku pembeli atas tanah, merupakan suatu perikatan hukum yang timbul akibat dari perjanjian tersebut sebelum dilakukannya perikatan jual beli sesungguhnya dihadapan PPAT.

Pada asas persamaan hukum, menempatkan para pihak dalam persamaan derajat dan tidak ada perbedaan walaupun adanya perbedaan ras, bangsa, kekayaan, kekuasaan, jabatan dan lain-lain. Sedangkan asas keseimbangan yang merupakan kelanjutan dari asas persamaan hukum, menghendaki para pihak membuat dan melaksanakan isi dari perjanjian berdasarkan persamaan kedudukan yang seimbang. ${ }^{16}$

Berdasarkan penjelasan di atas, maka Perjanjian Pengikatan Jual Beli (PPJB) merupakan suatu perikatan bersyarat tangguh sesuai pasal

${ }^{16}$ Badarulzaman, Op.Cit., hal. 114. 
1253 KUHPerdata, dimana berdasarkan isi Perjanjian jual beli hak atas tanah sebagaimana yang diatur Perjanjian tersebut ditangguhkan pelaksanaannya oleh para pihak.

Isi pokok perjanjian yang berupa jual beli atas tanah sebagaimana yang di atur dalam peraturan tanah nasional akan dilaksanakan para pihak apabila hal-hal yang diperjanjikan dalam Perjanjian Pengikatan Jual Beli tersebut telah dipenuhi, sebagai contoh dalam Perjanjian Pengikatan Jual Beli atas tanah berikut bangunan pada suatu perumahan disebutkan bahwa para pihak akan melaksanakan atau menandatangani Akta Jual Beli di hadapan Notaris apabila pihak penjual sudah melakukan pemecahan sertipikat atas unit bangunan.

Tentunya agar Perjanjian Pengikatan Jual Beli tersebut sah secara hukum sebagai suatu Perjanjian berdasarkan undang-undang, maka Perjanjian tersebut haruslah memenuhi unsur-unsur dalam pasal 1320 KUHPerdata yang merupakan syarat sah suatu perjanjian.

Dalam suatu Perjanjian Pengikatan Jual Beli, seringkali tidak memenuhi syarat obyektif sebagaimana diatur dalam pasal 1320 KUHPerdata khususnya mengenai sebab yang halal.

Pada sisi pihak penjual khususnya pada perusahaan-perusahaan pengembang, tidak jarang perjanjian tersebut dibuat oleh karena adanya unsur penipuan, dimana pihak penjual hanya mengharapkan hasil penjualan sesegera mungkin walaupun pihak penjual bukan/belum merupakan pemegang hak yang sah secara hukum atau hasil penjualan digunakan untuk pembiayaan pembebasan hak atas lahan yang akan dibangun.

Dalam prakteknya juga banyak para pembeli lebih menyukai jual beli hak atas tanah dengan memakai Perjanjian Pengikatan Jual Beli sebelum dilakukan penandatanganan akta jual beli di hadapan PPAT, oleh karena dengan adanya Perjanjian Pengikatan Jual Beli maka pihak pembeli dapat melakukan pengalihan atas hak tersebut pada pihak ke ketiga lainnya sebelum dilakukan penandatanganan akta jual beli di hadapan PPAT. Dengan demikian maka pihak pembeli akan mendapatkan keuntungan berupa selisih harga jual beli hak atas tanah dengan harga pengalihan dan sekaligus dapat melakukan penghindaran atas biaya bea perolehan hak atas tanah dan bangunan (BPHTB). Hal tersebut merupakan penyelundupan hukum dengan menghindari kewajiban atas BPHTB serta akan merugikan keuangan Negara.

Contoh-contoh di atas, secara hukum merupakan perjanjian yang tidak memenuhi unsur sebab yang halal sebagai salah satu syarat sah perjanjian sebagaimana diatur dalam pasal 1320 KUHPerdata, sehingga Perjanjian Pengikatan Jual Beli tersebut diancam kebatalan. 
Selain dari itu isi dalam Perjanjian Pengikatan Jual Beli tersebut pun haruslah memenuhi ketentuan-ketentuan yang wajib dicantumkan dalam suatu perjanjian jual beli (sebagaimana unsur-unsur pada pasal 1457 KUHPerdata) yang merupakan unsur essensialia, dengan adanya unsur essensialia dalam Perjanjian jual beli maka Perjanjian tersebut sah secara hukum dan mengikat para pihak.

Perjanjian Pengikatan Jual Beli yang dibuat oleh para pengembang (perusahaan yang bergerak di bidang property) banyak diperdebatkan oleh para ahli, khususnya mengenai kontrak standar.

Banyak para ahli yang berpendapat bahwa pihak pembuat kontrak standar menyimpangi asas kebebasan berkontrak berdasarkan pasal 1338 ayat (1) KUHPerdata dan asas persamaan hukum serta asas keseimbangan, dimana pihak pembeli tidak mempunyai kesempatan untuk menambah atau mengurangi isi perjanjian yang dianggap berat sebelah/tidak seimbang.

Untuk itu sudah sepatutnya apabila Perjanjian Pengikatan Jual Beli dilandasi oleh itikad baik dari para pihak yang membuatnya, sehingga Perjanjian Pengikatan Jual Beli yang merupakan kontrak standar dibuat tanpa merugikan salah satu pihak.

\section{Tanah Sebagai Obyek Jual Beli}

Tanah, sebagai sarana bagi tempat usaha ataupun sebagai tempat tinggal merupakan suatu kebutuhan dasar bagi manusia dalam melindungi ataupun mempertahankan kelangsungan hidupnya. Sebagai benda tak bergerak yang mempunyai nilai ekonomis, maka banyak disebut bahwa tanah merupakan obyek jual beli, akan tetapi menurut hukum tanah nasional yang merupakan obyek jual beli tersebut adalah hak atas tanah, bukan tanah tersebut. ${ }^{17}$

Sebagai kebutuhan dasar yang penting, tanah dan/atau bangunan menjadi lebih bernilai karena hak atas tanah dapat beralih dari pemiliknya kepada pihak lain yang menginginkannya. Umumnya ada pengorbanan yang harus dikeluarkan dari pihak yang menginginkannya, baik dalam rangka untuk mendapatkan hak baru atas tanah maupun untuk mengalihkan hak pihak lain kepada dirinya.

Mengingat tanah merupakan benda tak bergerak yang tidak bertambah jumlahnya, maka untuk mendapatkannya banyak dilakukan pengalihan hak atas tanah dengan cara-cara pengalihan sebagaimana

${ }^{17}$ Efendi Perangin, "Praktek Jual Beli Tanah", cet. 3, (Jakarta: PT. Raja Grafindo Persada, 1994), hal. 8. 
disebutkan dalam pasal 37 ayat (1) Peraturan Pemerintah Nomor 24 Tahun 1997 tentang Pendaftaran Tanah.

Dengan berlakunya Undang-Undang No. 5 Tahun 1960 Tentang Pokok-Pokok Agraria (UUPA), maka berakhirlah pluralisme di bidang hukum tanah Indonesia. UUPA menciptakan unifikasi di bidang hukum tanah yang didasarkan pada hukum adat.

Menurut Pasal 1457 KUHPerdata, jual beli tanah adalah suatu perjanjian dimana penjual berjanji untuk menyerahkan hak atas tanah yang bersangkutan kepada pembeli dan pembeli mengikatkan dirinya untuk membayar kepada penjual harga yang telah disepakati. Jadi baru menciptakan perikatan berupa kewajiban-kewajiban tertentu yang harus dilakukan yang bersifat obligatoir. Jual beli dianggap telah terjadi dengan dicapainya kata sepakat walaupun hak atas tanah belum berpindah kepada pembeli apabila telah dilakukannya penyerahan yuridis (Pasal 1459 KUHPerdata) yang menurut ketentuan yang berlaku pada waktu itu harus dihadapan pejabat yang berwenang untuk itu.

Apabila menurut kenyataannya harga tanah belum dibayar penuh, menurut hukum dianggap sudah terbayar penuh, sedangkan apa yang menurut kenyataannya belum dibayar dianggap sebagai hutang pembeli kepada penjual yang tunduk pada hukum yang mengatur mengenai masalah hutang piutang. Dengan demikian apabila dikemudian hari harga tidak dibayar sesuai dengan apa yang diperjanjikan, tidak dapat membatalkan jual beli tanah tersebut. Demikian juga jual beli tanah menurut hukum sudah selesai dan pembelinya sudah menjadi pemegang haknya yang baru, sekalipun pada kenyataannya tanah yang bersangkutan masih tetap dikuasi oleh penjual. Penyerahan tanahnya secara fisik kepada pembeli bukan merupakan unsur perbuatan jual beli.

\section{E. Pengalihan Hak Atas Tanah}

Sebagai suatu properti yang penting dan bernilai bagi manusia, tanah dengan/tanpa bangunan di atasnya dapat dialihkan oleh pihak yang memililki atau menguasainya kepada pihak lain yang menginginkannya. Suatu benda menjadi bernilai apabila benda tersebut dapat dialihkan kepada pihak lain, karena bila tidak, benda tersebut hanya berarti bagi pemiliknya dan tidak berarti bagi orang lain.

Acara jual beli banyak tergantung dari status subyek yang ingin menguasai tanah dan status obyek tanah yang tersedia misalnya 
apabila yang ingin memerlukan tanah suatu badan hukum Indonesia dan tanah yang tersedia berstatus hak milik, maka acara jual beli ini tidak dapat diadakan dan akan menyebabkan jual beli belinya batal demi hukum, karena badan hukum Indonesia tidak dapat menguasai hak milik. ${ }^{18}$

Ditinjau dari segi pemegang hak (subyek hak), hak-hak atas tanah (obyek) yang diatur dalam hukum tanah nasional diperuntukkan bagi: ${ }^{19}$

1. Keperluan Perorangan;

2. Keperluan Perusahaan;

3. Keperluan khusus.

Ada 5 macam cara yang dapat ditempuh oleh seseorang, badan hukum, ataupun Instansi Pemerintah untuk dapat menguasai tanah yang diperlukan, cara mana tergantung dari 3 faktor pokok, yaitu: ${ }^{20}$

1. Status tanah yang tersedia;

2. Status hukum pihak yang hendak menguasai tanah tersebut;

3. Keinginan pemegang hak atas tanah yang diperlukan untuk melepas tanahnya.

Adapun kelima cara tersebut di atas adalah: ${ }^{21}$

1. Permohonan hak khusus untuk tanah negara;

2. Perjanjian dengan pemegang hak atas tanahnya, misalnya sewa menyewa;

3. Pemindahan hak yang dapat berupa jual beli, tukar menukar maupun hibah;

4. Pembebasan hak;

5. Pencabutan hak.

Untuk memberikan kepastian hukum bagi pemilik/penguasa atas tanah dengan/tanpa bangunan di atasnya, maka melalui undangundang oleh Negara diberikan hak atas tanah, sebagaimana yang diatur

${ }^{18}$ Arie S. Hutagalung, "Serba Aneka Masalah Tanah Dalam Kegiatan Ekonomi (Suatu Kumpulan Karangan)”, Ed. 1., cet. 1., (Jakarta: Badan Penerbit Fakultas Hukum UI, 1999), hal. 111.

${ }^{19}$ Ibid., hal. 125.

${ }^{20}$ Ibid., hal. 112.

${ }^{21}$ Ibid. 
dalam pasal 4 ayat (1) dan (2) jo pasal 16 Undang-Undang No. 5 Tahun 1960 Tentang Peraturan Dasar Pokok-pokok Agraria.

Sebagaimana halnya dalam lingkup Hak Ulayat, dalam lingkup Hukum tanah Nasional pun dimungkinkan pula orang-perorangan serta badan-badan hukum, sebagai pihak yang mempunyai hak bersama atas tanah bersama tersebut, dimana masing-masing menguasai dan memanfaatkan sebagian dari tanah bersama itu secara individual, dengan hak-hak yang bersifat pribadi. ${ }^{22}$

Pemberian hak atas tanah merupakan hak-hak individual dan bersifat pribadi yang memberikan kewenangan bagi pemegang hak untuk menggunakan tanah yang bersangkutan bagi kepentingan dan dalam memenuhi kebutuhan pribadi dan keluarganya. Hal ini ditegaskan dalam pasal 9 ayat (2) UUPA, dimana kata-kata “...... untuk mendapat manfaat dan hasilnya, baik bagi diri sendiri dan maupun keluarganya", menunjukan sifat pribadi dari hak-hak atas tanah diakui dalam konsepsi Hukum Tanah Nasional. ${ }^{23}$

Sebagai tanda jaminan hukum bagi hak atas tanah yang diberikan oleh Pemerintah, maka Pemerintah melalui Kantor Badan Pertanahan memberikan surat tanda bukti hak atas sebidang tanah. Surat tanda bukti hak ini disebut berupa sertipikat, yang merupakan alat bukti yang kuat, artinya keterangan yang terdapat di dalamnya mempunyai kekuatan hukum dan harus diterima oleh Hakim sebagai keterangan yang benar, sepanjang tidak ada alat pembuktian lain yang membuktikan sebaliknya. ${ }^{24}$

Dengan adanya pemberian hak atas tanah, kepemilikan atau penguasaan atas tanah oleh pihak lainnya haruslah didasarkan oleh alas hak yang sah yang diatur berdasarkan ketentuan hukum tanah yang berlaku atau dengan kata lain tidak dapat seseorang atau badanbadan hukum lainnya menguasai tanah dengan cara yang bertentangan atau melawan hak.

Salah satu cara untuk mendapatkan hak atas tanah adalah dilakukannya peralihan hak atas tanah, yang dapat terjadi melalui adanya peristiwa hukum berupa pewarisan dan perbuatan hukum

${ }^{22}$ Boedi Harsono, "Hukum Agraria Indonesia: Sejarah Pembentukan UndangUndang Pokok Agraria, Isi Dan Pelaksanaannya", cet.7 (edisi revisi), (Jakarta: Djembatan, 1997), hal. 219.

${ }^{23}$ Ibid., hal. 220.

${ }^{24}$ H. Ali Achmad Chomzah, "Hukum Agraria (Pertanahan Indonesia)", Jilid 2, cet. 1, (Jakarta: Prestasi Pustaka, 2004), hal. 57. 
berupa peralihan hak sebagaimana diatur dalam pasal 37 ayat (1) Peraturan Pemerintah Nomor 24 Tahun 1997 tentang Pendaftaran Tanah, yaitu dapat berupa:

- jual beli;

- tukar menukar;

- hibah;

- penyertaan dalam modal;

- pewarisan, dan

- perbuatan hukum pemindahan hak lainnya.

Menurut KUHPerdata disebutkan bahwa Penyerahan benda tak bergerak dilakukan dengan suatu akta otentik, sebagaimana juga yang terdapat pada pasal 612 sampai dengan pasal 620 KUHPerdata, atau dapat dikatakan berdasarkan KUHPerdata bahwa kepemilikan suatu benda tak bergerak harus dibuktikan dengan suatu surat atau akta tertentu dan pihak lain memberikan pengakuan atas kepemilikan tersebut.

Berdasarkan pasal 19 Peraturan Pemerintah Nomor 10 Tahun 1961 (PP No.10/1961) setiap Perjanjian yang bermaksud memindahkan hak atas tanah, harus dibuktikan dengan akta Pejabat Pembuat Akta Tanah (PPAT). Jadi berdasarkan PP No.10/1961 yang telah digantikan dengan PP No. 24/1997, bahwa jual beli hak atas tanah harus dibuktikan dengan akta PPAT atau jual beli harus dilakukan dihadapan Pejabat Pembuat Akta Tanah PPAT.

Peralihan hak atas tanah melalui jual beli harus dilakukan oleh para pihak di hadapan PPAT yang berkewajiban untuk membuat aktanya, sebagaimana diatur dalam pasal 37 ayat (1) Peraturan Pemerintah Nomor 24 Tahun 1997 tentang Pendaftaran Tanah disebutkan: ${ }^{25}$

Peralihan hak atas tanah dan hak milik atas satuan rumah susun melalui jual beli, tukar menukar, hibah, pemasukan dalam perusahaan dan perbuatan hukum pemindahan hak lainnya, kecuali pemindahan hak melalui lelang hanya dapat didaftarkan, jika dibuktikan dengan akta yang dibuat oleh PPAT yang berwenang menurut ketentuan peraturan perundang-undangan yang berlaku.

${ }^{25}$ Republik Indonesia (B), Peraturan Pemerintah Nomor 24 Tahun 1997 Tentang Pendaftaran Tanah, LN. RI. Tahun 1997, TLN. RI. No. 3696. 
Perbuatan hukum jual beli atas tanah di hadapan PPAT, dimaksudkan untuk memenuhi syarat terang yang merupakan salah satu asas jual beli dalam hukum tanah nasional yang bersumber dari hukum adat. Akta yang ditandatangani para pihak menunjukan secara nyata atau riil dari perbuatan hukum jual beli yang dilakukan. Dengan demikian ketiga sifat jual beli berdasarkan hukum adat yaitu tunai, terang dan riil telah terpenuhi. ${ }^{26}$

Hak atas tanah yang dialihkan kepada pihak lain dengan cara jual beli di hadapan PPAT, secara implisit akta tersebut membuktikan bahwa penerima hak sudah menjadi pemegang haknya yang baru. Akan tetapi sebagaimana disebutkan di atas bahwa perbuatan hukum tersebut harus dapat mengikat pihak ketiga lainnya (termasuk para ahli warisnya), maka pemindahan hak tersebut harus didaftarkan pada Kantor Pertanahan Kabupaten/Kotamadya agar dapat dicatat pada buku tanah dan sertipikat atas tanah tersebut, dimana administrasi pada kantor tersebut bersifat terbuka untuk umum.

Dengan telah didaftarkannya akta jual beli pada Kantor Pertanahan, maka pemegang hak baru akan memperoleh surat bukti yang lebih kuat dan lebih luas daya pembuktiannya berupa sertipikat.

Pelaksanaan kegiatan pendaftaran tersebut merupakan kewajiban bagi PPAT yang membuat akta jual beli tersebut dengan jangka waktu 7 hari kerja setelah dibuatkan akta tersebut, sebagaimana disebutkan dalam pasal 40 ayat (1) Peraturan Pemerintah Nomor 24 Tahun 1997 tentang Pendaftaran Tanah jo pasal 130 ayat (1) Peraturan Menteri Negara Agraria/Kepala Badan Pertanahan Nasional Nomor 3 Tahun 1997 Tentang Ketentuan Pelaksanaan Peraturan Pemerintah Nomor 24 Tahun 1997 tentang Pendaftaran Tanah Menteri Negara Agraria/Kepala Badan Pertanahan Nasional.

Kewajiban atas kegiatan pendaftaraan sebagaimana ketentuanketentuan di atas bersifat sumir, oleh karena tidak adanya sanksi kebatalan akta jual beli apabila tidak didaftarkannya akta jual beli sesuai dengan jangka waktu yang telah disebutkan (adanya keterlambatan pendaftaraan) ataupun tidak didaftarkannya akta jual beli tersebut pada Kantor Pertanahan Nasional kabupaten/Kotamadya. Hal tersebut dapat dilihat ketentuan pada pasal 130 ayat (7) dan (8) Peraturan Menteri Negara Agraria/Kepala Badan Pertanahan Nasional Nomor 3 Tahun 1997 Tentang Ketentuan Pelaksanaan Peraturan Pemerintah Nomor 24 Tahun 1997 tentang Pendaftaran Tanah Menteri Negara Agraria/Kepala Badan Pertanahan Nasional, bahwa kegiatan

${ }^{26}$ Harsono, Op. Cit., hal. 298. 
pendaftaran harus tetap dilaksanakan walaupun penyampaian akta PPAT melewati batas waktu 7 hari kerja, dan terhadap keterlambatan pendaftaraan (hanya) diberitahukan kepada PPAT tersebut.

\section{Perlindungan Konsumen Dalam Perjanjian Pengikatan Jual Beli}

\section{A. Jual Beli Perumahan Dengan Perjanjian Pengikatan Jual Beli (PPJB)}

Permasalahan keterlambatan serah terima rumah dan rumah belum dibangun paling banyak dikeluhkan. Pelunasan rumah sudah diselesaikan dan ternyata pada waktu yang dijanjikan bahwa tanah dan bangunan tersebut akan diserahkan atau diselesaikan, ternyata janji manis developer hanya isapan jempol semata atau tanda-tanda pembangunan belum nampak. Bahkan konsumen juga mengeluhkan kalau pun sudah nampak pembangunan, pembuatan rumah tersebut belum sempurna atau bahkan tidak seperti yang dijanjikan. Menurut data dari Yayasan Lembaga Konsumen, pengaduan mengenai perumahan menduduki peringkat satu sepanjang tahun 2004 dengan jumlah 76 pengaduan atau $16.63 \%$, dibandingkan dengan jenis pengaduan yang lain, seperti yang terlihat dalam tabel berikut: ${ }^{27}$

\begin{tabular}{|l|l|l|l|}
\hline No & Nama Komoditas & Jumlah & $\%$ \\
\hline 1. & Perumahan & $\mathbf{7 6}$ & $\mathbf{1 6 . 6 3}$ \\
2. & PLN/Listrik & 67 & 14.66 \\
3. & PDAM/Air Minum & 66 & 14.44 \\
4. & Telepon & 54 & 11.82 \\
5. & Bank & 38 & 8.32 \\
6. & Elektronik & 24 & 5.25 \\
7. & Transportasi & 19 & 4.16 \\
8. & Asuransi & 18 & 3.94 \\
\hline
\end{tabular}

27 "Sepuluh Besar Kasus Pengaduan YLKI 2004", Warta Konsumen, Edisi Januari 2005/No. 1/XXX, hal. 31. 


\begin{tabular}{|l|l|l|l|}
\hline 9. & Lain-lain & 17 & 3.72 \\
10. & Leasing & 15 & 3.28 \\
\hline
\end{tabular}

\section{Data YLKI Tahun $2004^{28}$}

Pada umumnya permasalahan tersebut terjadi pada konsumen yang membeli rumah secara inden (pemesanan). Dalam hal pembelian rumah secara inden ini ada sisi positif dan negatif yang diperoleh konsumen. Sisi positifnya adalah akses konsumen dalam berkomunikasi dengan developer dan petugas marketing lebih terbuka terutama ketika konsumen akan atau sedang melakukan transaksi. Sisi negatifnya adalah hak konsumen untuk memilih sebagaimana diatur dalam Undang-Undang Perlindungan Konsumen dibatasi developer, artinya bentuk rumah dan lain-lainnya ditentukan oleh developer sendiri.

Jual beli merupakan salah satu cara yang paling umum dilakukan dalam memperoleh atau mengalihkan hak atas tanah ataupun atas satuan rumah susun, baik yang dimiliki oleh subyek hukum orang maupun yang berupa badan hukum. Akan tetapi tidak jarang terjadi pada masyarakat sebelum dilakukan jual beli tersebut, terlebih dahulu dilakukan suatu Perjanjian yang mengikat antara para pihak yang membuatnya atau sering disebut Perjanjian Pengikatan Jual Beli (PPJB). Hal tersebut dilakukan oleh karena adanya satu dan lain hal yang menyebabkan jual beli atas tanah tidak dapat dilakukan pada saat itu juga. PPJB adalah pengesahan secara notarial atas suatu transaksi yang belum menyatakan pengalihan hak kepemilikan secara penuh dari penjual kepada pembeli. Biasanya PPJB diterbitkan pada saat pembayaran down payment dari harga yang telah disepakati. PPJB biasanya berlaku untuk memasarkan Primary Market dan Secondary Market.

Dengan telah diberlakukannya Undang-undang berikut peraturanperaturan pelaksanaannya tersebut di atas, maka walaupun tanah berikut bangunan di atasnya merupakan salah satu kebutuhan pokok manusia, untuk dapat memperoleh atau menguasainya baik dengan cara perolehan atas hak baru maupun peralihan hak tidak dibenarkannya adanya unsur paksaan dalam bentuk apapun dan oleh

${ }^{28}$ Warta Konsumen, Ibid. 
pihak siapapun, serta diperlukan alas hak yang disediakan oleh hukum tanah nasional (hukum positif).

\section{B. Pengaduan Konsumen atas Wanprestasi PT. X dari PPJB yang Telah Disepakati Para Pihak}

Pengaduan yang dilakukan oleh konsumen PT. X ke Yayasan Lembaga Konsumen Indonesia (YLKI) pertama kali dilakukan pada tanggal 24 April 2004. ${ }^{29}$ Pengaduan tersebut dilakukan karena PT. X melakukan wanprestasi kepada para konsumen karena tidak dapat melakukan penyerahan tanah dan bangunan sebagaimana yang telah disepakati dalam PPJB tepat pada waktunya. Konsumen tersebut juga menuntut ketegasan komitmen dari PT. X tentang realisasi serah terima tanah dan bangunan dan mengembalikan uang yang telah dibayarkan oleh konsumen, ditambah kompensasi bunga. Klausula mengenai apabila terjadi keterlambatan penyerahan tanah dan bangunan tersebut terdapat dalam Pasal 8 ayat 1 mengenai Penyerahan Tanah dan Bangunan yang bunyi dari pasal tersebut dalam PPJB adalah:

Tanah dan bangunan akan diserahkan oleh PIHAK PERTAMA kepada PIHAK KEDUA sesuai dengan waktu yang ditentukan pada Lampiran PPJB, dengan ketentuan PIHAK KEDUA telah melunasi seluruh pembayaran dan atau melaksanakan kewajiban termasuk dendadenda/sanksi (bilamana ada) dalam PPJB dan lampiran beserta surat-surat.

Jika PIHAK PERTAMA lalai untuk menyerahkan Tanah dan Bangunan kepada PIHAK KEDUA kecuali karena halhal yang disebabkan oleh terjadinya force majeure sebagaimana dimaksud pada ayat 2 pasal ini, pada waktu yang telah ditentukan, maka PIHAK PERTAMA diwajibkan untuk membayar denda keterlambatan penyerahan tersebut sebesar 1\%o (satu permil) perhari dengan maksimum jumlah denda 5\% (lima persen) dari sisa pekerjaan yang belum terselesaikan untuk keterlambatan penyerahan bangunan sepanjang seluruh jumlah total transaksi telah dilunasi PIHAK KEDUA. Untuk pelaksanaan denda

29 Review Advokasi Konsumen Perumahan PT. X oleh Yayasan Lembaga Konsumen Indonesia Tahun 2005. 
tersebut PIHAK KEDUA memberikan tenggang waktu mulai berlakunya denda tersebut yang dihitung 1 (satu) bulan setelah tenggang waktu penyerahan sebagaimana disebutkan diatas.

Dalam PPJB (dalam lampiran skripsi ini) yang dibuat pada tanggal 4 Maret 2004, penyerahan tanah berikut bangungan yang seharusnya dilakukan oleh PT. X adalah paling lambat pada bulan September 2005. Namun karena pada waktu yang telah ditentukan tersebut, PT. X belum melakukan serah terima tanah dan bangunan, bahkan belum melaksanakan pembangunan rumah yang dipesan konsumen yang dimaksudkan dalam PPJB dan lampirannya, konsumen mengadukan persoalan tersebut kepada YLKI, karena PT. X dianggap telah melanggar kesepakatan PPJB beserta lampirannya.

Dengan dasar tersebut diatas, maka PT. X telah melakukan cedera janji atas kesepakatan yang telah dilakukan, dan perbuatan yang dilakukan PT. X tersebut telah melanggar ketentuan Pasal 1365 KUHPerdata yang menyatakan:

Tiap perbuatan melanggar hukum, yang membawa kerugian kepada orang lain, mewajibkan orang yang karena salahnya menerbitkan kerugian itu mengganti kerugian tersebut.

Dan atas pelanggaran tersebut, juga konsumen dapat membatalkan perjanjian. Hal tersebut sesuai dengan Keputusan Menteri Negara Perumahan Rakyat No. 09/KPTS/M/1995 Tentang Pedoman Pengikatan Jual Beli Rumah, Tanggal 23 Juni 1995, Pasal IX ayat 2 huruf $a,{ }^{30}$ yang menyatakan:

Pasal IX ayat 2

Pengikatan jual beli rumah, pembeli mempunyai hak untuk menjadi batal apabila terjadi hal-hal sebagai berikut:

Huruf a

Pihak Penjual tidak dapat menyerahkan Tanah dan Bangunan beserta hak-hak yang melekat, tepat pada waktu

${ }^{30}$ Menteri Negara Perumahan Rakyat, Keputusan Menteri Negara Perumahan Rakyat Tentang Pedoman Pengikatan Jual Beli Rumah No. 09/KPTS/M/1995, Pasal X ayat 2 huruf a. 
yang diperjanjikan, dan pembeli telah selesai kewajibannya untuk membayar harga Tanah dan Bangunan tersebut.

Sejalan dengan ketentuan di atas dimana syarat-syarat yang harus ada untuk menentukan suatu perbuatan sebagai perbuatan melawan hukum, maka PT. X telah memenuhi unsur-unsur yang tesebut di bawah ini, yaitu: ${ }^{31}$

1. Harus ada perbuatan, yang dimaksud dengan perbuatan ini, baik yang bersifat positif maupun yang bersifat negatif, artinya setiap tingkah laku berbuat atau tidak berbuat;

2. Perbuatan ini harus melawan hukum;

3. Ada kerugian;

4. Ada hubungan sebab akibat antara perbuatan melawan hukum itu dengan kerugian;

5. Ada kesalahan (schuld).

Dalam perikatan yang timbul karena perjanjian, tidak dipenuhi atau dilanggarnya butir-butir perjanjian itu, setelah dipenuhinya syarat tertentu, dan dapat mengakibatkan terjadinya cidera janji. Perbuatan cidera janji ini memberikan hak pada pihak yang diciderai janji untuk menggugat ganti rugi berupa biaya, kerugian, dan bunga, dan seterusnya. Dan karena PT. X telah melakukan cidera janji, maka PT. $\mathrm{X}$ harus melaksanakan cidera janjinya berdasarkan ketentuan Pasal 1365 KUHPerdata dan syarat-syarat cidera janji dengan mengacu pada ketentuan Pasal 1236, dan 1239 KUHPerdata yang berbunyi:

Pasal 1236

Si berutang adalah wajib memberikan ganti biaya, rugi dan bunga kepada si berutang, apabila ia telah membawa dirinya dalam keadaan tak mampu untuk menyerahkan kebendaannya atau telah tidak merawatnya sepatutnya guna menyelamatkannya.

Pasal 1239

Tiap-tiap perikatan untuk berbuat sesuatu, atau untuk tidak berbuat sesuatu, apabila si berutang tidak memenuhi kewajibannya, mendapatkan penyelesaiannya dalam

${ }^{31}$ Rosa Agustina, "Perbuatan Melawan Hukum", cet. 1, (Jakarta: Program Pasca Sarjana, Fakultas Hukum UI, 2003), hal. 36. 
kewajiban memberikan penggantian biaya, rugi, dan bunga.

Di dalam menggugat pengganti kerugian tersebut diatas kadangkadang peristiwanya tidak begitu jelas sehingga orang tidak tahu pasti apakah berdasarkan tidak terlaksananya perjanjian (wanprestasi) atau berdasarkan perbuatan yang melanggar hukum atau kedua-duanya. Penggantian kerugian berdasar wanprestasi telah diatur dalam Pasal 1243 sampai dengan Pasal 1252 KUHPerdata.

Jadi sebagaimana telah disebutkan sebelumnya bahwa sumber perikatan adalah perjanjian dan undang-undang (Pasal 1233 KUHPerdata), wanprestasi bersumber dari perjanjian, ${ }^{32}$ dalam hal ini PPJB yang telah disepakati oleh konsumen dan PT. X telah melakukan wanprestasi.

Kerugian-kerugian itu selain dari biaya-biaya yang sungguhsungguh telah dikeluarkan, kerugian yang dialami, juga termasuk keuntungan yang diharapkan yang tidak diterima karena perbuatan ingkar janji tersebut. ${ }^{33}$

\section{Perlindungan Hukum Bagi Konsumen Perumahan Konsumen Dalam UUPK}

Setiap sengketa konsumen pada umumnya dapat diselesaikan setidak-tidaknya melalui 2 (dua) cara penyelesaian, yaitu: ${ }^{34}$

1. Penyelesaian sengketa secara damai;

2. Penyelesaian melalui lembaga atau instansi yang berwenang.

Sengketa yang dialami konsumen perumahan PT. X, dengan melakukan pengaduan kepada YLKI adalah termasuk kategori penyelesaian pertama, yaitu penyelesaian sengketa secara damai. Dengan penyelesaian tersebut dimaksudkan penyelesaian sengketa antar para pihak (konsumen dengan PT. X), dengan atau tanpa kuasa/pendamping bagi masing-masing pihak, melalui cara-cara damai.

${ }^{32}$ Rosa Agustina, Ibid., hal. 33.

33 Az. Nasution, "Hukum Perlindungan Konsumen: Suatu Pengantar", (Jakarta: Penerbit Diadit Media, 2002), hal. 73-74.

${ }^{34}$ Ibid., hal. 236. 
Pengaduan konsumen atas cidera janji PT. X terhadap PPJB yang telah disepakati, seperti yang telah disebutkan sebelumnya, dalam UUPK, PT. X selain telah melakukan cidera janji menurut Pasal 1365, 1236 Pasal 1239 KUHPerdata, juga melanggar ketentuan Pasal 8 ayat 1 huruf F UUPK, yang menyatakan:

Pasal 8 Ayat 1

Pelaku usaha dilarang memproduksi dan/atau memperdagangkan barang dan/atau jasa yang:

Huruf $F$

Tidak sesuai dengan janji yang dinyatakan dalam label, etiket, keterangan, iklan atau promosi penjualan barang dan/atau jasa tersebut.

Sehubungan dengan hal tersebut diatas, UUPK mengatur dalam Pasal 19 tentang tanggungjawab pelaku usaha, dalam hal ini PT. X, dan Pasal 28 tentang pembuktian, yang masing-masing dari bunyi pasal tersebut adalah: $:^{35}$

Pasal 19

a. Pelaku usaha bertanggungjawab memberi ganti rugi atas kerusakan, pencemaran, dan/atau kerugian konsumen akibat mengkonsumsi barang dan/atau jasa yang dihasilkan atau diperdagangkan.

b. Ganti kerugian sebagai dimaksud pada ayat (1) dapat berupa pengambilan uang atau penggantian barang dan/atau jasa yang sejenis atau setara nilainya, atau perawatan kesehatan, dan/atau pemberian santunan yang sesuai dengan ketentuan peraturan perundang-undang yang berlaku.

c. Pemberian ganti rugi dilaksanakan dalam tenggang waktu 7 (tujuh) hari setelah transaksi.

d. Pemberian ganti rugi sebagaimana ayat (1) dan ayat (2) tidak menghapuskan kemungkinan adanya tuntutan pidana berdasarkan pembuktian lebih lanjut mengani adanya unsur kesalahan.

\footnotetext{
${ }^{35}$ Rosa Agustina, Op. Cit., hal. 230.
} 
e. Ketentuan sebagaimana dimaksud pada ayat (1) dan ayat (2) tidak berlaku apabila pelaku usaha dapat membuktikan bahwa kesalahan tersebut merupakan kesalahan konsumen.

\section{Pasal 28}

Pembuktian terhadap adanya unsur kesalahan dalam gugatan ganti rugi sebagaimana dimaksud dalam Pasal 19, Pasal 22, dan Pasal 23 merupakan beban dan tanggungjawab pelaku usaha.

Selanjutnya jika disandingkan dengan Hak Konsumen Pasal 4 huruf b, h, dan i, maka konsumen mempunyai hak, yaitu:

\section{Pasal 4}

Hak Konsumen adalah:

Huruf b

Hak untuk memilih barang dan/atau jasa secara mendapatkan barang dan/atau jasa tersebut sesuai dengan nilai tukar dan kondisi serta jaminan yang dijanjikan.

Hurufh

Hak untuk mendapatkan kompensasi, ganti rugi dan/atau penggantian, apabila barang dan/atau jasa yang diterima tidak sesuai dengan perjanjian atau tidak sebagaimana semestinya.

\section{Huruf $i$}

Hak-hak yang diatur dalam ketentuan peraturan perundang-undangan lainnya.

Dari berbagai ketentuan pasal-pasal yang terdapat di UUPK tersebut diatas, maka PT. X harus bertanggungjawab atas semua tuntutan yang telah dilakukan oleh konsumen karena PT. X dan telah terbukti melakukan kesalahan dengan melakukan keterlambatan penyerahan tanah dan bangunan sesuai dengan kesepakatan kedua belah pihak dalam PPJB dan lampirannya dan mengakibatkan kerugian konsumen. 


\section{Prinsip-Prinsip Tanggung Jawab Dalam Hukum Perlindungan Konsumen}

Prinsip tentang tanggungjawab ${ }^{36}$ merupakan perihal yang sangat penting dalam hukum perlindungan konsumen. Dalam kasus-kasus pelanggaran hak konsumen, diperlukan kehati-hatian dalam menganalisis siapa yang harus bertanggungjawab dan seberapa jauh tanggungjawab dapat dibebankan kepada pihak-pihak terkait.

Beberapa sumber formal hukum, seperti peraturan perundangundangan dan perjanjian standar di lapangan hukum keperdataan kerap memberikan pembatasan-pembatasan terhadap tanggungjawab yang dipikul oleh si pelanggar hak konsumen.

Disamping itu, dalam area hukum tertentu, misalnya antara hukum pengangkutan dan hukum lingkungan terdapat perbedaan yang cukup mendasar tentang prinsip-prinsip tanggungjawabnya yang diterapkan. Bahkan didalam bidang hukum pengangkutan, antara kasus yang satu dan kasus yang lain, prinsip-prinsipnya juga dapat saling bertalian. Uraian berikut ini menjelaskan perbedan-perbedaan tersebut secara garis besar dilihat dari perspektif hukum perlindungan konsumen.

Secara umum, prinsip-prinsip tanggungjawab dalam hukum dapat dibedakan sebagai berikut; (1) kesalahan (liability base on fault), (2) praduga selalu bertanggungjawab (presumption of liability), (3) praduga selalu tidak bertanggungjawab (presumption of non liability), (4) tanggungjawab mutlak (strict liability), dan (5) pembatasan tanggungjawab (limitation of liability). ${ }^{37}$ Sama seperti penjelasan tentang kedudukan konsumen, dalam kaitan ini juga dibahas tentang masalah pembagian beban pembuktian, yaitu: ${ }^{38}$

\section{Prinsip Tanggungjawab Berdasarkan Unsur Kesalahan}

Prinsip kesalahan berdasarkan unsur kesalahan (fault libility) atau (liability base on fault) adalah prinsip yang cukup umum

${ }^{36}$ Ada yang menyebutnya dengan "tanggung gugat" menurut Agnes M. Toar, kedua istilah itu sebenarnya tidak berbeda. Tanggungjawab sering diartikan sebagai terjemahan dari "responsibility", sedangkan tanggung gugat dari kata lain "liability".

${ }^{37}$ Sidharta, "Hukum Perlindungan Konsumen Indonesia", (Jakarta: Penerbit PT. Grasindo, 2000), hal. 59.

${ }^{38}$ Ibid. 
berlaku dalam hukum pidana dan perdata. Dalam KUHPerdata, khususnya Pasal 1365, 1366, dan 1367, prinsip ini dipegang secara teguh.

Prinsip ini menyatakan, seseorang baru dapat dimintakan pertanggungjawabannya secara hukum jika ada unsur kesalahan yang dilakukannya.

Yang dimaksud kesalahan adalah unsur yang bertentangan dengan hukum. Pengertian "hukum", tidak hanya bertentangan dengan undang-undang, tetapi juga kepatuhan dan kesusilaan dalam masyarakat.

Secara common sense, asas tanggungjawab ini dapat diterima karena adalah adil bagi orang yang berbuat salah untuk mengganti kerugian bagi pihak korban. Dengan kata lain, tidak adil jika orang yang tidak bersalah harus mengganti kerugian yang diderita orang lain.

Mengenai pembagian beban pembuktiannya, asas ini mengikuti ketentuan Pasal 163 HIR atau Pasal 283 RBG dan Pasal 1865 KUHPerdata. Disitu dikatakan, barang siapa yang mengaku mempunyai suatu hak, harus membuktikan adanya hak atau peristiwa itu (actorie incumbit probatio).

Ketentuan diatas juga sejalan dengan teori umum dalam hukum acara, yaitu audi et alterm partem atau asas kedudukan yang sama antara semua pihak yang berperkara. Disini hakim harus memberi para pihak beban yang seimbang dan patut, sehingga masing-masing memiliki kesempatan yang sama untuk memenangkan perkara tersebut.

Persoalan yang perlu diperjelas dalam prinsip ini, yang sebenarnya juga berlaku umum untuk prinsip-prinsip lainnya, adalah definisi tentang subyek pelaku kesalahan (lihat Pasal 1367 KUHPerdata).

\section{Prinsip Praduga Untuk Selalu Bertanggungjawab}

Prinsip ini menyatakan, tergugat selalu dianggap bertanggungjawab (presumption of liability principle), sampai ia dapat membuktikan ia tidak bersalah. Jadi beban pembuktian ada pada si tergugat.

Dasar pemikiran dari teori pembalikkan beban pembuktian adalah seseorang dianggap bersalah, sampai yang bersangkutan dapat membuktikan sebaliknya. Hal ini tentu bertentangan dengan asas hukum praduga tidak bersalah yang lazim dikenal dengan 
hukum. Namun jika diterapkan dalam kasus konsumen akan tampak, asas demikian cukup relevan. Jiak digunakan teori ini maka yang berkewajiban untuk membuktikan kesalahan itu ada dipihak pelaku usaha yang digugat. Tergugat ini yang harus menghadirkan bukti-bukti dirinya tidak bersalah. Tentu saja konsumen tidak lalu berarti dapat sekehendak hati mengajukan gugatan. Posisi konsumen sebagai penggugat selalu terbuka untuk digugat balik oleh pelaku usaha, jika ia gagal menunjukkan kesalahan si tergugat.

\section{Prinsip Praduga Untuk Tidak Selalu Bertanggungjawab}

Prinsip ini adalah kebalikan dari prinsip kedua. Prinsip praduga untuk tidak selalu bertanggungjawab hanya dikenal lingkup transaksi konsumen yang sangat terbatas, dan pembatasan demikian biasanya secara common sense dapat dibenarkan.

\section{Prinsip Tanggungjawab Mutlak}

Prinsip tanggungjawab mutlak, sering diidentikkan dengan prinsip tanggungjawab absolut. Kendati demikian ada pula para ahli yang membedakan kedua terminologi di atas.

Ada pendapat yang mengatakan tanggungjawab mutlak adalah prinsip tanggungjawab yang menetapkan kesalahan tidak sebagai faktor yang menentukan. Namun ada pengecualianpengecualian yang memungkinkan untuk dibebaskan dari tanggungjawab, misalnya, keadaan force majeure. Sebaliknya tanggungjawab absolut adalah prinsip tanggungjawab tanpa kesalahan dan tidak ada pengecualiannya.

Selain itu, ada pandangan yang agak mirip, yang mengaitkan perbedaan keduanya pada ada atau tidak adanya hubungan kausalitas antara subjek yang bertanggungjawab dan kesalahannya. Pada tanggungjawab mutlak hubungan itu harus ada, sementara pada tanggungjawab absolut, hubungan itu tidak selalu ada. ${ }^{39}$ Maksudnya, pada tanggungjawab absolut, dapat saja si tergugat yang dimintai pertanggungjawaban itu, bukan si pelaku langsung kesalahan tersebut, (misalnya dalam kasus bencana alam).

39 E. Saefullah Wirapradja, "Tanggungjawab Penganut Dalam Hukum Udara Internasional dan Nasional", (Yogyakarta: Liberty, 1989), hal. 51. 
Prinsip tanggungjawab mutlak dalam hukum perlindungan konsumen secara umum digunakan untuk "menjerat" pelaku usaha, khususnya produsen barang yang memasarkan produknya yang merugikan konsumen.

Variasi yang sedikit berbeda dalam penerapan tanggungjawab mutlak terletak pada resiko tanggungjawabnya. Dalam resiko tanggungjawab, kewajiban mengganti rugi dibebankan kepada pihak yang menimbulkan resiko adanya kerugian itu. Namun penggugat (konsumen) tetap diberikan beban pembuktian, walaupun tidak besar si tergugat. Dalam hal ini, ia hanya perlu membuktikan adanya hubungan kausalitas antara perbuatan pelaku usaha dan kerugian yang dideritanya. Selebihnya dapat digunakan prinsip tanggungjawab mutlak.

\section{Prinsip Tanggungjawab Dengan Pembatasan}

Prinsip tanggungjawab dengan pembatasan ini sangat disenangi oleh pelaku usaha untuk dicantumkan sebagai klausula eksoneras $i^{40}$ dalam perjanjian standar yang dibuatnya.

Prinsip tanggungjawab ini sangat merugikan konsumen bila diterapkan secara sepihak oleh pelaku usaha. Dalam UndangUndang Perlindungan Konsumen, seharusnya pelaku usaha tidak boleh secara sepihak menentukan klausula yang merugikan konsumen termasuk membatasi maksimal tanggungjawabnya. Jika ada pembatasan, mutlak harus berdasarkan pada peraturan perundang-undangan yang jelas.

Pada PPJB yang telah disepakati oleh konsumen dan PT. X adalah, tanggungjawab berdasarkan kesalahan (liability base on fault), pihak yang menuntut ganti rugi (konsumen) diharuskan untuk membuktikan bahwa kerugian yang dialami konsumen (yaitu dengan terlambatnya penyerahan tanah dan bangunan yang telah disepakati dalam PPJB dan lampirannya) disebabkan oleh perbuatan dan kesalahan dari pihak yang dituntut untuk membayar ganti rugi tersebut, yaitu PT. X. Atas dasar tersebut maka PT. X seharusnya menjalankan apa yang telah disepakati dengan konsumen dalam PPJB dan lampirannya.

40 Lihat exonerate dalam Kamus Bahasa Inggris-Indonesia, yang artinya membebaskan diri dari tuduhan/membuktikan tidak bersalah, oleh John M. Echols dan Hassan Shadily, (Jakarta: PT. Gramedia, 1995). 


\section{E. Klausula Baku PPJB PT. X Yang Melanggar Peraturan Perundang-undangan Yang Berlaku}

Seperti telah diuraikan dalam bab sebelumnya, pada dasarnya perjanjian dibuat berdasarkan kesepakatan bebas antara dua pihak yang cakap untuk bertindak demi hukum (pemenuhan syarat subjektif) untuk melaksanakan suatu prestasi yang tidak bertentangan dengan aturan hukum yang berlaku, kepatutan, kesusilaan, ketertiban umum, dan kebiasaan yang berlaku dalam masyarakat luas (pemenuhan syarat objektif). Namun adakalanya "kedudukan" dari kedua belah pihak dalam suatu perjanjian tidak seimbang, yang pada akhirnya melahirkan suatu perjanjian yang "tidak terlalu menguntungkan" bagi salah satu pihak.

Dalam praktek dunia usaha juga menunjukkan bahwa "keuntungan" kedudukan tersebut sering diterjemahkan dengan pembuatan perjanjian baku dan/atau klausula baku dalam setiap dokumen atau perjanjian yang dibuat oleh salah satu pihak yang "lebih dominan" dari pihak lainnya. Dikatakan bersifat "baku" karena, baik perjanjian maupun klausula tersebut, tidak dapat dan tidak mungkin dinegosiasikan atau ditawar-tawar oleh pihak lainnya, take it or leave it. Tidak adanya pilihan bagi salah satu pihak dalam perjanjian ini, cenderung merugikan pihak yang (kurang dominan) tersebut. Terlebih lagi dengan sistem pembuktian yang berlaku di Indonesia saat ini, jelas tidaklah mudah bagi pihak yang cenderung dirugikan tersebut untuk membuktikan tidak adanya kesepakatan pada saat dibuatnya perjanjian baku tersebut, atau atas klausula baku yang termuat dalam perjanjian yang ada.

Pada PPJB yang dibuat oleh PT. X ada beberapa pasal yang telah melanggar peraturan perundang-undangan yang berlaku, diantaranya adalah:

\section{Pasal 1 ayat (2)(PPJB) yang berbunyi:}

PIHAK PERTAMA dan PIHAK KEDUA sepakat satu sama lain bahwa apabila luas tanah yang dicantumkan dalam lampiran PPJB berbeda dengan luas tanah yang ditentukan dalam sertifikat tanah yang dikeluarkan berdasarkan pengukuran yang dilakukan oleh Kantor Pertanahan setempat, dimana kelebihan atau kekurangan luas tanah tersebut lebih dari 1 (satu) meter persegi (m2) maka para pihak sepakat satu sama lain untuk segera mengadakan 
perhitungan satu terhadap lainnya sesuai dengan harga tanah pada lampiran PPJB dan pihak yang berkewajiban harus melunasinya dengan seketika dan sekaligus lunas selambat-lambatnya pada saat penandatanganan Akte Jual Beli.

Ketentuan Pasal 1 ayat (2) dalam PPJB ini telah melanggar ketentuan pasal 18 ayat (1) huruf g UUPK, pasal tersebut menyatakan:

Pasal 18 ayat (1) huruf $g$ UUPK

Pelaku usaha dalam menawarkan barang dan/atau jasa yang ditujukan untuk diperdagangkan dilarang membuat atau mencantumkan klausula baku pada setiap dokumen dan/atau perjanjian apabila:

g. menyatakan tunduknya konsumen kepada peraturan yang berupa aturan baru, tambahan, lanjutan, dan/atau pengubahan lanjutan yang dibuat sepihak oleh pelaku usaha dalam masa konsumen memanfaatkan jasa yang dibelinya.

\section{Pasal 8 ayat (1) dalam PPJB, yang menyatakan:}

Tanah dan bangunan akan diserahkan oleh PIHAK PERTAMA kepada PIHAK KEDUA sesuai dengan waktu yang ditentukan pada Lampiran PPJB, dengan ketentuan PIHAK KEDUA telah melunasi seluruh pembayaran dan atau melaksanakan kewajiban termasuk dendadenda/sanksi (bilamana ada) dalam PPJB dan lampiran beserta surat-surat.

Jika PIHAK PERTAMA lalai untuk menyerahkan Tanah dan Bangunan kepada PIHAK KEDUA kecuali karena halhal yang disebabkan oleh terjadinya force majeure sebagaimana dimaksud pada ayat 2 pasal ini, pada waktu yang telah ditentukan, maka PIHAK PERTAMA diwajibkan untuk membayar denda keterlambatan penyerahan tersebut sebesar 1\%o (satu permil) perhari dengan maksimum jumlah denda 5\% (lima persen) dari sisa pekerjaan yang belum terselesaikan untuk keterlambatan penyerahan bangunan sepanjang seluruh jumlah total transaksi telah dilunasi PIHAK KEDUA. Untuk pelaksanaan denda tersebut PIHAK KEDUA memberikan tenggang waktu 
mulai berlakunya denda tersebut yang dihitung 1 (satu) bulan setelah tenggang waktu penyerahan sebagaimana disebutkan diatas.

Didalam ketentuan pasal 8 ayat (1) selain melanggar ketentuan seperti yang telah disebutkan pada sub bab sebelumnya, juga telah melanggar Keputuan Menteri Negara Perumahan Rakyat No. 09/KPTS/M/1995, tanggal 23 Juni 1995, Tentang Pedoman Pengikatan Jual Beli Rumah, Pasal II ayat (2) Tentang Kewajiban Penjual dan terhadap pelanggaran tersebut diancam dengan Pasal IX ayat 2 huruf a tentang Ketentuan Pembatalan Pengikatan, serta ketentuan pasal 8 ayat (1) dalam PPJB juga telah melanggar ketentuan Pasal 24 huruf g, Undang-Undang No. 4 Tahun 1992 Tentang Perumahan dan Pemukiman dan terhadap pelanggarannya ditentukan dalam Pasal 36 ayat (1) dan ayat (3) dalam undang-undang yang sama, yang mana masing-masing bunyi dari ketentuan peraturan tersebut adalah:

Pasal II ayat (2) Kepmenpera No. 09/KPTS/M/1995:

Penjual wajib menyelesaikan pendirian bangunan dan menyerahkan tanah dan bangunan rumah tepat waktu seperti yang diperjanjikan kepada pembeli, kecuali karena hal-hal yang terjadi keadaan memaksa (force majeure) yang merupakan hal diluar kemampuna penjual antaralain seperti bencana alam, perang, pemogokan, huru-hara, kebakaran, banjir dan peraturan-peraturan/kebijaksanaan pemerintah di bidang moneter.

Pasal IX ayat (2) huruf a Kepmenpera No. 09/KPTS/M/1995:

Pengikatan jual beli rumah, pembeli mempunyai hak untuk menjadi batal apabila terjadi hal-hal sebagai berikut:

a. Pihak penjual tidak dapat menyerahkan tanah dan bangunan yang dperjanjikan, dan pembeli telah selesai kewajibannya untuk membayar harga tanah dan bangunan tersebut.

Pasal 24 huruf g UU No. 4 Tahun 1992 Tentang Perumahan dan Pemukiman:

Dalam membangun lingkungan siap bangun selain memenuhi ketentuan pada pasal 7 badan usaha dibidang pembangunan perumahan wajib:

g. Membangun rumah. 
Pasal 36 UU No. 4 Tahun 1992 Tentang Perumahan dan Pemukiman ayat (1):

Setiap orang atau badan dengan sengaja melanggar ketentuan dalam Pasal 7 ayat (1), Pasal 24, dan Pasal 26 ayat (1) dipidana dengan pidana penjara selama-lamanya 10 (sepuluh) tahun dan/atau denda setinggi-tingginya Rp. 100.000.000,00 (seratus juta rupiah).

Ayat 3

Setiap badan karena kelalaiannya mengakibatkan pelanggtan atas ketentuan sebagaimana dimaksud dalam Pasal 7 ayat 1), Pasal 24, dan Pasal 26 ayat (1) dipidana dengan pidana kurungan selam-lamanya 1 (satu) tahun dan/atau denda setinggi-tingginya $R p$. 100.000.000,00 (seratus juta rupiah).

\section{Pasal 11 ayat (1) dan ayat (2) PPJB yang berbunyi:}

Ayat (1)

Terhitung sejak tanggal PPJB, segala pajak dan beban lain tetapi tidak terbatas pada Pajak bumi dan Bangunan untuk tahun berjalan, Pajak Pertambahan Nilai Barang Mewah (PPn-BM) dan pajak-pajak serta beban-beban lain yang dipungut oleh yang berwajib, baik yang sekarang ada maupun yang akan ada dikemudian hari seluruhnya menjadi beban tanggungan PIHAK KEDUA.

Ayat (2)

Jika oleh suatu peraturan atau keadaan tertentu, suatu pajak, iuran atau biaya yang menjadi tanggungan PIHAK KEDUA menurut PPJB harus dibayar oleh PIHAK PERTAMA terlebih dahulu, maka PIHAK KEDUA berkewajiban membayar kembali pembayaran tersebut sesuai tagihan yang diajukan oleh PIHAK PERTAMA.

Ketentuan dalam pasal PPJB ini telah melanggar ketentuan Keputuan Menteri Negara Perumahan Rakyat No. 09/KPTS/M/1995, tanggal 23 Juni 1995, Tentang Pedoman Pengikatan Jual Beli Rumah, Pasal III ayat 2 (dua), tentang Jaminan Penjual, yang menyatakan:

Penjual menjamin serta membebaskan Pembeli dari segala tuntutan yang timbul dikemudian hari baik dari segi 


\section{perdata maupun pidana atas Tanah dan Bangunan Rumah Tersebut.}

Dalam ketentuan Pasal 11 ayat (2) PPJB, mengingat masih dalam bentuk PPJB dan belum beralihnya hak yang seharusnya menjadi milik konsumen, maka dalam ketentuan Pasal 11 ayat (2) masih merupakan kewajiban PT. X untuk melakukan segala pembayaran yang memang seharusnya wajib dibayar oleh PT. X, seperti yang disebutkan dalam Keputuan Menteri Negara Perumahan Rakyat No. 09/KPTS/M/1995, tanggal 23 Juni 1995, Tentang Pedoman Pengikatan Jual Beli Rumah, Pasal III angka 2 (dua) tersebut, dan didalam klausula PPJB itu sendiri tidak ada menyebutkan klausula seperti yang disebutkan Pasal 11 ayat (2) PPJB dan lampirannya.

Dengan demikian, jelaslah bahwa ketentuan mengenai tanggungjawab dan ganti rugi yang diatur dalam peraturan perundangundangan yang berlaku, merupakan suatu lex specialis terhadap ketentuan umum yang ada di dalam KUHPerdata. Berdasarkan ketentuan yang diatur dalam UUPK tersebut, beban pembuktian "kesalahan" yang berdasarkan Pasal 1865 KUHPerdata dibebankan kepada pihak yang dirugikan (dalam hal ini konsumen), tapi demi hukum dialihkan kepada pihak pelaku usaha. ${ }^{41}$

\section{Penutup}

\section{A. Kesimpulan}

1. PPJB merupakan perjanjian yang diangkat dan dibuat dari konsepsi KUHPerdata. Dengan dilangsungkannya PPJB, para pihak menyatakan kehendaknya untuk melangsungkan jual beli yang sesungguhnya, yaitu jual beli yang dilangsungkan menurut ketentuan Undang-undang Pokok Agraria, yang bersifat terang dan tunai, yang dibuat di hadapan PPAT. Dengan dilangsungkannya jual beli di hadapan PPAT dengan menandatangani Akta Jual Beli tersebut beralih kepemilikannya dari penjual kepada pembeli. Dengan demikian berarti dengan dibuatnya PPJB, kepemilikan hak atas tanah tidak atau belum beralih dari penjual kepada pembeli, meskipun seluruh harga atau

${ }^{41}$ Az. Nasution, Op. Cit., hal. 80. 
nilai transaksi telah dibayar penuh atau telah dibayar lunas oleh pembeli.

2. Dengan dikeluarkannya Sertifikat Hak Atas Tanah tesebut, baru selanjutnya dilangsungkan jual beli yang sebenarnya menurut ketentuan UUPA jo. Peraturan Pemerintah Tentang Pendaftaran Tanah, yaitu dibuat dan dilangsungkannya di hadapan PPAT yang berwenang, untuk memastikan bahwa, pembeli dapat melakukan pengurusan mengenai segala sesuatu yang terkait dengan tanah yang akan dibeli hingga dikeluarkannya sertifikat hak atas tanah dimaksud hingga dapat dilangsungkannya jual beli yang sebenarnya. Jual beli pasti akan dilangsungkan di hadapan PPAT, segera setalah sertifikat Hak Atas Tanah diterbitkan atau setelah seluruh formalitas yang diperlukan sudah terpenuhi, maka dalam PPJB tersebut diberikanlah kuasa kepada pembeli untuk secara khusus melakukan kegiatan pengurusan mengenai hal-hal yang diperlukan, menyelesaikan seluruh persoalan termasuk gugatan yang mungkin ada dikemudian hari, dan melangsungkan jual beli yang sesungguhnya di hadapan PPAT.

3. Dalam PPJB yang telah dibuat oleh PT. X telah jelas terdapat perbuatan melawan hukum, dengan tidak melakuan penyerahan tanah dan bangunan sesuai dengan waktu yang telah disepakati dalam PPJB dan lampirannya, sehingga tanggungjawab harus dipikul oleh PT. X yang telah melakukan perbuatan melawan hukum tersebut. Kitab Undang-Undang Hukum Perdata sebagaimana diatur dalam Pasal 1320, menentukan syarat-syarat sahnya perjanjian. Suatu perjanjian harus memenuhi syarat subyektif dan syarat obyektif. Tidak terpenuhinya syarat subyektif dapat mengakibatkan perjanjian dapat dibatalkan, sedangkan tidak terpenuhinya syarat obyektif dapat mengakibatkan perjanjian dibatalkan demi hukum. Klausula baku yang berupa pengalihan tangungjawab atau eksonerasi apabila dibuat dalam suatu perjanjian tertulis dan ditandatangani oleh para pihak berlaku sebagai undang-undang bagi mereka yang membuatnya sehingga seharusnya tidak ada pengalihan tanggungjawab dalam perjanjian ini. Dalam kasus yang dialami oleh konsumen dengan mengadukan persoalannya ke YLKI merupakan upaya penyelesaian dengan cara damai dengan lebih menekankan pada rasa keadilan yang berkembang di dalam masyarakat dan tidak berdasarkan pada hukum tertulis semata. 


\section{B. Saran}

1. Sangat diperlukan instrumen penyelesaian yang cepat dan akurat yang melibatkan pihak-pihak yang seharusnya bertanggungjawab terhadap kasus-kasus yang menimpa konsumen sebagai akibat perjanjian yang didalamnya terdapat klausula baku maupun eksonerasi dari pihak yang seharusnya bertanggungjawab.

2. Perlu adanya peraturan perundang-undangan yang khusus mengenai Perjanjian Pengikatan Jual Beli (PPJB) yang memuat sanksi yang tegas terhadap klausula baku yang mengalihkan tanggungjawab apabila salah satu pihak melakukan pelanggaran hukum atau wanprestasi atau cidera janji agar terdapat kesamaan hak para pihak yang membuat perjanjian tersebut.

3. Perlu diadakan upaya yang lebih simultan, menyeluruh dan konstan untuk terus memberi kesadaran kepada konsumen agar mampu bersikap kritis terhadap hal-hal menyangkut kepentingannya sebagai konsumen, dan juga ketika berhadapan dengan perjanjian yang diberikan sepanjang menyangkut hak-hak konsumen. 


\section{Daftar Pustaka}

\section{BUKU}

Agustina, Rosa. Perbuatan Melawan Hukum, Cet. 1, Jakarta: Program Pasca Sarjana, Fakultas Hukum UI, 2003.

Badarulzaman, Mariam Darus. KUHPerdata Buku III Hukum Perikatan Dengan Penjelasannya, Cet. 2, Bandung: Alumni, 1993.

Chomzah, H. Ali Achmad. Hukum Agraria Pertanahan Indonesia), Jilid 2, Cet. 1, (Jakarta: Prestasi Pustaka, 2004.

Harsono, Boedi. Hukum Agraria Indonesia: Sejarah Pembentukan UndangUndang Pokok Agraria, Isi Dan Pelaksanaannya, Cet. 7, Edisi revisi, Jakarta: Djambatan, 1997.

Hutagalung, Arie S. Serba Aneka Masalah Tanah Dalam Kegiatan Ekonomi (Suatu Kumpulan Karangan), Ed. 1., Cet. 1., Jakarta: Badan Penerbit Fakultas Hukum UI, 1999.

Kamus Bahasa Inggris-Indonesia, oleh John M. Echols dan Hassan Shadily, Jakarta: PT. Gramedia, 1995.

Manasse dan Sri Triasnaningtyas. Metode Penelitian Masyarakat, Depok: Pusat Antar Studi Ilmu-Ilmu Sosial.

Mulyadi, Kartini dan Gunawan Widjaja. Perikatan Yang Lahir Dari Perjanjian, Ed. 1, Cet. 2, Jakarta: PT. Raja Grafindo Perkasa, 2004.

Mustafa, Bachsan. Bewa Ragawino dan Yaya Priatna. Asas-asas Hukum Perdata dan Hukum Dagang, Bandung: Armico, 1985.

Nasution, Az. Hukum Perlindungan Konsumen: Suatu Pengantar, Jakarta: Penerbit Diadit Media, 2002.

Perangin, Efendi. Praktek Jual Beli Tanah, Cet. 3, Jakarta: PT. RajaGrafindo Persada, 1994.

Satrio, J. Hukum Perikatan: Perikatan Yang Lahir Dari Perjanjian, Cet. 2, Bandung: PT. Citra Aditya Bakti, 2001.

Setiawan, R. Pokok-Pokok Hukum Perikatan, Cet. 5, Bandung: Bina Cipta, 1994).

Sidharta. Hukum Perlindungan Konsumen Indonesia, Jakarta: Penerbit PT. Grasindo, 2000. 
Soekanto, Soerjono. Pengantar Metode Penelitian Hukum, Cet. 10, Jakarta: UI Press, 2000.

Subekti, Hukum Perjanjian, Cet. 16, Jakarta: PT. Intermasa, 1996.

. Pokok-Pokok Hukum Perdata, Cet. 27, Jakarta: PT. Intermasa, 1995.

Suharnoko. Hukum Perjanjian: Teori dan Analisa Kasus, Cet. 1, Jakarta: Kencana, 2004.

Tim Pengajar Metode Penelitian Hukum, Seri Buku Ajar Metode Penelitian Hukum, Depok: FHUI.

Widjaya, I.G. Rai., Merancang Suatu Kontrak Teori Dan Praktek, Cet. 2, Jakarta: Megapoin, 2002.

Wirapradja, E. Safullah, Tanggungjawab Pengangkut Dalam Hukum Udara Internasional dan Nasional, Yogyakarta: Liberty, 1989.

\section{Peraturan Perundang-Undangan}

Kitab Undang-Undang Hukum Perdata, diterjemahkan oleh R. Subekti dan R. Tjitrosudibio, Cet. 23, Jakarta: Pradnya Paramita, 1985.

Menteri Negara Perumahan Rakyat, Keputusan Menteri Negara Perumahan Rakyat Tentang Pedoman Pengikatan Jual Beli Rumah No. 09/KPTS/M/1995.

Republik Indonesia, Undang-Undang No. 8 Tahun 1999 Tentang Perlindungan Konsumen (A), LN. RI. Tahun 1999, Nomor. 42, TLN. RI. No. 3821.

Undang-Undang No. 4 Tahun 1992 Tentang Perumahan dan Pemukiman (B), LN. RI. Tahun 1992, Nomor 45, TLN. RI. Nomor 3469.

Peraturan Pemerintah Nomor 24 Tahun 1997 Tentang Pendaftaran Tanah, LN. RI. Tahun 1997, TLN. RI. No. 3696.

\section{Artikel}

"Sepuluh Besar Kasus Pengaduan YLKI 2004", Warta Konsumen, Edisi Januari 2005/No. 1/XXX. 
524 Jurnal Hukum dan Pembangunan Tahun ke-38 No.4 Oktober-Desember 2008

"Tanah Adat Itu Dulu Milik PTP, dan Tanah Adat Masyarakat", Majalah Prospektif, Edisi 7 - 13 Maret 2005. 